\title{
Mutational spectrum of Gelsolin and its down regulation is associated with breast cancer
}

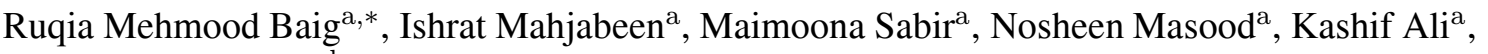 \\ Faraz Arshad Malik ${ }^{\mathrm{a}, \mathrm{b}}$ and Mahmood Akhtar Kayani ${ }^{\mathrm{a}}$ \\ ${ }^{a}$ Cancer Genetics Lab, Department of Biosciences, COMSATS Institute of Information Technology, Chak shazad, \\ Islamabad, Pakistan \\ ${ }^{\mathrm{b}}$ Metastasis and Angiogenesis Research Group, Institute of Cancer and Genetics, Cardiff University School of \\ Medicine, Cardiff, $U K$
}

\begin{abstract}
Cytoskeletal rearrangement occurs in variety of cellular processes and involves a wide spectrum of proteins. Gelsolin super family proteins control actin organization by severing and capping filament ends and nucleating actin assembly. Gelsolin is the founding member of this family and plays important role in pathogenesis of human neoplasia.

This study aimed to investigate the germline mutations and expressional profile of Gelsolin in human breast cancer tissues. For germ line screening PCR-SSCP technique was used while expression was analyzed through quantitative real time PCR. Different types of mutations were observed in Gelsolin coding regions on exons 4, 10,11, 14 and 15. These mutations include 3 missense nonsynonymous substitution mutations, 2 deletions, 1 insertion and 1 synonymous substitution mutation. Gelsolin transcript level was found significantly lower in breast tumor tissues compared to control samples $(p=0.03)$. Low level of Gelsolin was found in metastatic patients $(p=0.002)$ and patients who died from breast cancer $(P=0.03)$ compared to disease free patients at final follow up. This study shows that level of Gelsolin is down regulated in breast cancer tissues and is linked with metastasis development and death in patients. It is concluded that genetic changes in coding regions of Gelsolin can potentially contribute to genetic instability. These genetic variations and expressional correlation with patient survival may prove to be of significant importance.
\end{abstract}

Keywords: Gelsolin, germline mutations, PCR-SSCP, expressional analysis, quantitative real time PCR, breast cancer

\section{Introduction}

Gelsolin protein super family is a conserved family of proteins present in mammalian and non-mammalian organisms [22]. This super family consists of seven different proteins that contain homologous repeats of gelsolin-like $(\mathrm{G})$ domain. Gelsolin, a protein of $82-$ $84 \mathrm{kDa}$, is the founding member of this family encoded by a gene on chromosome 9 . It exists as a cytoplasmic as well as a plasma isoform and can bind, sever and cap actin filaments [21]. It is expressed in a

*Corresponding author: Ruqia Mehmood Baig, Cancer Genetics Lab, Department of Biosciences, COMSATS Institute of Information Technology, Park Road, Chak shazad, Islamabad, Pakistan. Tel.: +92 313 5400921; Fax: +92 51 9247006; E-mail: ruqiamehmood@ gmail.com. wide variety of cell types and contains six gelsolin-like (G) domains. It was first described as a protein able to bind and sever actin filaments, and to control polymerization of barbed ends. This protein also initiates formation of actin filaments by binding two monomeric actin molecules. Gelsolin activity is regulated by $\mathrm{Ca}^{+2}$, intracellular $\mathrm{pH}$, phosphoinositides and tyrosine phosphorylation [12,14,27,38,50]. It is a downstream effector of Rac for motility in dermal fibroblasts and regulates phosphoinositide signaling pathways and ion channel function in vivo. It also acts as a regulator and effector of apoptosis [38]. Gelsolin is one of the most important actin structure regulating proteins. Its expression in almost all eukaryotic cells shows its fundamental importance in maintaining an organized actin cytoskeleton $[8,9]$. 
HeLa cells that normally do not express gelsolin are rendered more susceptible to apoptosis by over expressing gelsolin [51]. Point mutations in mouse gelsolin grant it tumor-suppressor activity against $\mathrm{H}$ ras oncogenes transformed NIH $3 \mathrm{t} 3$ cells. Gelsolin has a histidine instead of a proline residue at position 321 and suppresses the tumorigenicity of EJ-NIW3T3 (ras oncogene-transformed NW3T3 cells) cells [16,56]. Moreover, transfection of the gelsolin gene in a human bladder cancer cell line strongly reduces colonyforming ability and tumorigenicity in vivo [42]. It has been reported that gelsolin promoter activity is much higher in normal mammary cells (184A1N4) than in breast cancer cells (T47D and MCF-7) [44]. Gelsolin as a cytoskeleton-regulated factor may control cell mobility and inhibit tumor growth and metastasis [38]. Expression of gelsolin is noted to be reduced in human cancer tissues, particularly in human breast cancer tissues and non-small cell lung carcinomas [31, 15,60]. Over-expression of gelsolin has been shown to inhibit metastasis in vivo by its binding with actin molecules [16].

Variations in gelsolin expression affect major cytoskeletal changes during differentiation and carcinogenesis. Diminished expression of gelsolin was observed in multiple transformed cells $[16,42]$. It is reported that gelsolin expression is significantly low in murine fibroblasts transformed by $H$-ras oncogene. [16]. In human fibroblasts and epithelial cells transformed with SV40 virus, gelsolin is one of the most striking down regulated markers of the transformed state [34]. Low or undetectable expression of gelsolin was observed in seven of the eight gastric carcinoma cell lines [58]. There have been similar reports of gelsolin expression in human breast cancers and colon cancers $[6,53]$. In a study 6 bladder cancer cell lines and 14 of the 18 bladder cancer tissues showed reduced or undetectable gelsolin expression compared with normal control bladder mucosa [45]. Gelsolin is able to bind PIP2 and can inhibit PIP2 hydrolysis by PLC $\gamma$ in vitro $[62,48]$, it was speculated that the tumor suppressive function of gelsolin is also provoked by the inhibition of signal transduction through phosphoinositides [45].

Partial or total loss of Gelsolin expression is commonly observed in breast cancer patients with an increase in PIP2 levels $[13,40]$. Similar to these observations Sagawa et al. [47], suggested that Gelsolin suppresses the activation of Protein kinase C (PKCs) thus inhibiting cell proliferation and tumor growth [47].

Several reports indicate that gelsolin acts as a tumor suppressor $[3,18,19,29,37,45,47,55]$. There are other studies who reported Gelsolin as a tumor activator [1, $5,23,35,36,39,57]$. It is perceived that role of Gelsolin as a tumor suppressor depends upon the type of cancer [25]. Abbeele et al. [4] showed that gelsolin act as a tumor activator as it's down regulation significantly reduces the invasive and motile properties of cells, as well as cell aggregation in vitro [4].

It has been observed that increased gelsolin expression may play a critical role in converting a superficial tumor to an invasive tumor [30]. Shieh et al. [11] observed a biphasic gelsolin expression pattern with limited gelsolin staining in oral pre-cancerous lesions and increased gelsolin staining in primary and metastatic lesions [11]. A decreased trend in Gelsolin expression was observed in malignant progression, from normal epithelium to DCIS to invasive breast cancer [19]. Down-regulation of gelsolin might have a role in progression of inverted papilloma [26].

Many studies have been reported in context to Gelsolin role in cancer but the presence of any germ line mutations on this gene in breast cancer patients has not been evaluated before. This work was planned to screen gelsolin for germ line mutations in sporadic breast cancer cases of Pakistani population. Breast cancer is one of the major death causes amongst women in world as well as in Pakistan [46,59]. Expression profile of gelsolin was also examined in breast cancer patients and compared with clinical outcomes of patients in the cohort.

\section{Materials and methods}

\subsection{Identification of patients and samples collection}

Present case-control study consisted of pathologically confirmed breast cancer cases. Two study groups were used in this study. The cohort\#1 was used for screening germline mutations. It consists of 350 blood samples along with age and gender matched, healthy and disease free normal individuals as controls. While cohort\#2 was used for evaluating Gelsolin expression at mRNA level and comprises 60 tissue samples. Tumor matched normal adjacent tissues were used as control. Presence of tumor cells in the collected tissues was verified by examination of frozen sections following $\mathrm{H}$ and $\mathrm{E}$ staining by a consultant pathologist. Details of the patients in study cohort\#1 and 2 are given in Tables 1 and 2 respectively. Samples were recruited from Nuclear medicine, Oncology and Radiotherapy Institute (NORI), Pakistan Institute of Medical Sci- 
Table 1

Characteristics of the study population (cohort\#1)

\begin{tabular}{lll}
\hline & Associated factors & Number of patients (P value) \\
\hline 1 & Age & \\
a & $\leqslant 40$ years & $123(<0.0001)$ \\
b & Above & 227 \\
2 & Age at menarche & \\
a & $<13$ years & $149(<0.0001)$ \\
b & $\geqslant 13$ years & 186 \\
c & $\geqslant 17$ years & 15 \\
3 & Age at first birth & \\
a & $<25$ years & $223(<0.0003)$ \\
b & $\geqslant 25$ years & 127 \\
4 & Menopausal status & \\
a & Pre menopausal & $146(<0.03)$ \\
b & Post menopausal & 204 \\
5 & Age at menopause & \\
a & $<48$ years & $126(<0.02)$ \\
b & $\geqslant 48$ years & 78 \\
\hline
\end{tabular}

ences (PIMS) Islamabad and Military Hospital (MH) Rawalpindi, Pakistan. These samples were collected with a prior approval from Ethical Committees of both CIIT and hospitals. All study subjects participated on a volunteer basis with informed consent.

\subsection{DNA isolation and quantification}

DNA was isolated from leukocytes (blood), using organic protocol with phenol-chloroform extraction as previously described [24,52]. Electrophoresis was performed on isolated DNA in $1 \%$ ethidium-bromide stained agarose gel and photographed (BioDocAnalyze Biometra). $5 \mathrm{ng} / \mu \mathrm{l}$ dilutions were made for isolated DNA sample and stored at $4{ }^{\circ} \mathrm{C}$ until further usage.

\subsection{RNA extraction and reverse transcription-polymerase chain reaction}

RNA was extracted using Trizol reagent in accordance with the provided protocol by manufacturer (Invitrogen, Scotland, UK) from tissue samples. Sample RNA was quantified using a spectrophotometer (WPA UV 1101, Biotech Photometer, Cambridge, UK) and standardized to a concentration of $500 \mathrm{ng}$ per reaction. This RNA was used as a template to reverse transcribe cDNA using the Super Script First-Strand Synthesis System (Invitrogen, USA)

\subsection{PCR amplifications, SSCP analysis and sequencing}

PCR amplifications were performed in $10 \mu \mathrm{l} \mathrm{PCR}$ mixture containing $2 \mu \mathrm{l}$ of each primer $(10 \mathrm{mM}), 5 \mu \mathrm{l}$ master mix, $1 \mu \mathrm{l}$ PCR water and $2 \mu \mathrm{l}(5 \mathrm{ng} / \mu \mathrm{l})$ extracted DNA. Reaction mixture was placed in 9700 thermal cycler/ Veriti of ABI systems. PCR profile consisted of an initial melting step of $94^{\circ} \mathrm{C}$ for 5 min, 35 cycles of $94^{\circ} \mathrm{C}$ for $40 \mathrm{sec}$, annealing at $55^{\circ} \mathrm{C}$ for 40 seconds and $72^{\circ} \mathrm{C}$ for $1 \mathrm{~min}$ and a final extension step of $72^{\circ} \mathrm{C}$ for $10 \mathrm{~min}$ and hold at $4^{\circ} \mathrm{C}$. All patients and control DNA was amplified for gelsolin gene with exon specific primers.

PCR product was analyzed by single stranded conformational polymorphism (SSCP) as previously described [24,52] and results were examined with gel documentation system (BioDocAnalyze Biometra) after ethidium bromide staining and photographed for further analysis. Amplified products showing abnormal SSCP patterns were prepared as per instructions and shipped to MCLab (USA) for DNA sequencing. The sequenced results were made forward complementary before analysis using BioEdit v 7.0.5 software and analyzed.

\subsection{Mutational analysis}

Sequencing results were analyzed via Alamut bio software version 2.0 for detection of mutation location as well as its effect on genomic, cDNA and protein level. Missense mutations were also predicted by Align GVGD and SIFT [49] using this software.

\subsection{Quantitative-Polymerase Chain Reaction $(Q-P C R)$}

Real-time quantitative PCR was used to assess gelsolin transcript levels as previously reported [2]. Results are given as number of transcripts/ $\mu$ l based on an internal standard and the results were further normalized using the expression of GAPDH in these samples. Q-PCR technique used the Amplifluor system (Intergen Inc., New York, US), Q-PCR Master Mix (ABgene, Surrey, UK) and a universal probe (Uniprimer ${ }^{\mathrm{TM}}$, Intergen) to record the fluorescence emitted by the $\mathrm{z}$ sequences. Conditions for Q-PCR were: an initial 15 minute $95^{\circ} \mathrm{C}$ period followed by 60 cycles of $95^{\circ} \mathrm{C}$ for 15 seconds, $55^{\circ} \mathrm{C}$ for 60 seconds and $72^{\circ} \mathrm{C}$ for 20 seconds.

\subsection{Statistical analysis}

Data were collected, compared and analyzed using a two-sample, two-tailed $t$-test. Data values given represent the mean value $\pm \mathrm{SEM}$, and values of $p \leqslant 0.05$ were considered to be statistically significant. Confidence Interval was calculated using the null hypothesis approach. 
Table 2

Clinical and pathological information of the study cohort\#2

\begin{tabular}{lllll}
\hline Grouping & Number & & \\
\hline Age & & & \\
$>50$ & 23 & & \\
$<50$ & 37 & Grade2 & Grade3 \\
Grades & Grade1 & 22 & 21 & \\
& 17 & Lobular & Others & \\
Histology & Ductal & 8 & 5 & Died of breast cancer \\
& 47 & With metastasis & With local reoccurrence & Died unrelated disease \\
Clinical outcome & Disease free & $\mathbf{3}$ & $\mathbf{5}$ \\
\hline
\end{tabular}

Table 3

Mutations observed in the Gelsolin gene in Breast Cancer Patients

\begin{tabular}{|c|c|c|c|c|c|c|c|}
\hline $\begin{array}{l}\text { No of } \\
\text { cases }\end{array}$ & $\begin{array}{l}\text { Frequency of } \\
\text { variation }\end{array}$ & OR $(95 \% \mathrm{CI})$ & Exon & cDNA level & Genomic level & Protein level & Effect \\
\hline 12 & 0.08 & $0.09(0.0053-1.5348)$ & 4 & $\begin{array}{l}\text { NM_001127662.1: } \\
\text { c. } 11 \mathrm{~A}>\mathrm{G}\end{array}$ & $\begin{array}{l}\text { Chr9(GRCh37): } \\
\text { g.124064260A>G }\end{array}$ & p.Glu4Gly & $\begin{array}{l}\text { Missense } \\
\text { substitution }\end{array}$ \\
\hline 27 & 0.186 & $0.22(0.0139-3.7747)$ & 11 & $\begin{array}{l}\text { NM_001127662.1: } \\
\text { c.985C >T } \\
\text { c.987_988del }\end{array}$ & $\begin{array}{l}\text { Chr9(GRCh37): } \\
\text { g.124080952C >T } \\
\text { g.124080954_124080955del }\end{array}$ & $\begin{array}{l}\text { p.Leu329Phe } \\
\text { p.Pro330X }\end{array}$ & $\begin{array}{l}\text { Missense substi- } \\
\text { tution\& } \\
\text { Deletion }\end{array}$ \\
\hline 18 & 0.124 & $0.14(0.008-2.3665)$ & 15 & $\begin{array}{l}\text { NM_001127662.1: } \\
\text { c. } 1637 \mathrm{~A}>\mathrm{T}\end{array}$ & $\begin{array}{l}\text { Chr9(GRCh37): } \\
\text { g.124089635A }>\text { T }\end{array}$ & p.Lys546 Ile & $\begin{array}{l}\text { Missense } \\
\text { substitution }\end{array}$ \\
\hline 36 & 0.248 & $0.33(0.0201-5.4173)$ & 10 & $\begin{array}{l}\text { NM_001127662.1: } \\
\text { c.897_898insGCAGGC }\end{array}$ & $\begin{array}{l}\text { Chr9(GRCh37):g.124080694_ } \\
\text { 124080695insGCAGGC }\end{array}$ & $\begin{array}{l}\text { p.Ala299_Asn300 } \\
\text { insAlaGly }\end{array}$ & $\begin{array}{l}\text { Insertion, Frame } \\
\text { shift mutation }\end{array}$ \\
\hline 20 & 0.137 & $0.16(0.0096-2.623)$ & 14 & $\begin{array}{l}\text { NM_001127662.1: } \\
\text { c.1436del }\end{array}$ & $\begin{array}{l}\text { Chr9(GRCh37): } \\
\text { g.124088809del }\end{array}$ & $\begin{array}{l}\text { p.Lys } 479 \\
\text { ArgfsX7 }\end{array}$ & $\begin{array}{l}\text { deletion, Frame } \\
\text { shift mutation }\end{array}$ \\
\hline 32 & 0.220 & $0.28(0.0172-4.6548)$ & 10 & $\begin{array}{l}\text { NM_001127662.1: } \\
\text { c.906G }>\text { A }\end{array}$ & $\begin{array}{l}\text { Chr9(GRCh37): } \\
\text { g.124080703G>A }\end{array}$ & p. $=$ & $\begin{array}{l}\text { Synonymous } \\
\text { substitution }\end{array}$ \\
\hline
\end{tabular}

\section{Results}

\subsection{Characteristics of the study population (cohort\#1)}

General characteristic features associated with breast cancer were studied in patients (Table 1). These features include patients age, age at menarche, age at first full term pregnancy and age at menopause. Mean age of patients were noted to be 47 years. Mean age at menarche was 13 years. Age at first full term pregnancy in $39 \%$ patients was $>25$ years while $61 \%$ had $<$ 25 years. While mean Age at menopause was 45 years.

\subsection{Mutational results}

An extensive screening of Gelsolin gene was conducted for mutations and variations among 350 samples and 350 cancers free control samples in study cohort\#1.

Different types of mutations were observed which include 3 nonsynonymous substitutions, 1 synonymous substitution, 3 frame shift mutations (comprising of 2 deletions and 1 insertion) (Table 3 ). Mutations described are of 7 different types and were observed in a total of 145 samples.

\subsection{Non-synonymous substitutions}

3 nonsynonymous substitution mutations at exon 4 , 11 and 15 were observed. Transition $A$ to $G$ in exon 4 "11A $>$ G" cause missense substitution mutation and change Glutamine at position 4 to Glycine in 12 samples (Fig. 1A). Transition $\mathrm{C}$ to $\mathrm{T}$, cause missense substitution mutation at exon 11 at position 985 by altering Leucine at position 329 to Phenylalanine in 27 samples (Fig. 1B). Transversion from $\mathrm{A}$ to $\mathrm{T}$ in exon 15 "1637A $>$ T" resulted in missense substitution by changing Lysine at amino acid position 546 to Isoleusine in 18 samples (Fig. 1C).

\subsection{Frame shift mutations}

One insertion and two deletion mutations were observed in this study. Insertion of 6 bps "GCAGGC" in exon 10 at position 897_898 caused the insertion of 2 residue (s) Alanine and Glycine in 36 samples (Fig. 1D). While deletion of 2bp "TC" and 1bp "A" observed at exon 11, position 987_988 in 27 samples (Fig. 1B) and at exon 14, position 1436 in 20 samples (Fig. 1E) respectively. 
Table 4

Distribution of Gelsolin mutation types among age group and menopausal status in Breast cancer patients

\begin{tabular}{|c|c|c|c|c|c|c|}
\hline Types of mutation & $\begin{array}{c}\text { Pre menopausal } \\
\mathrm{N}(\%)\end{array}$ & $\begin{array}{c}\text { Post menopausal } \\
\mathrm{N}(\%)\end{array}$ & OR $(95 \% \mathrm{CI})$ & $\begin{array}{c}\text { Age }<40 \\
\mathrm{~N} \%\end{array}$ & $\begin{array}{c}\text { Age }>40 \\
\mathrm{~N} \%\end{array}$ & OR $(95 \% \mathrm{CI})$ \\
\hline $11 \mathrm{~A}>\mathrm{G}$ & $5(41.6 \%)$ & $7(58.33 \%)$ & $1.1224(0.3465-3.6355)$ & $3(25 \%)$ & $9(75 \%)$ & 0.548 \\
\hline 985C $>\mathrm{T}$ 987_988 TC/- & $9(33.3 \%)$ & $18(66.6 \%)$ & $0.7606(0.3279-1.7643)$ & $4(14.48 \%)$ & $23(85.18 \%)$ & $0.2644(0.0887-0.788)$ \\
\hline $1637 \mathrm{~A}>\mathrm{T}$ & $7(38.8 \%)$ & $11(61.1 \%)$ & $0.9943(0.3726-2.6537)$ & $4(22.2 \%)$ & $14(77.77 \%)$ & $0.4606(0.1474-1.4394)$ \\
\hline 897_898_/GCAGGC & $12(33.33 \%)$ & $24(66.6 \%)$ & $0.7527(0.3584-1.5807)$ & $16(44.4 \%)$ & $20(55.5 \%)$ & $1.414(0.6962-2.8721)$ \\
\hline $1436 \mathrm{~A} /-$ & $11(55 \%)$ & $9(45 \%)$ & $2.0193(0.8062-5.058)$ & $13(65 \%)$ & $7(35 \%)$ & $3.443(1.3258-8.9413)$ \\
\hline $906 \mathrm{G}>\mathrm{A}$ & $13(56.52 \%)$ & $19(82.60 \%)$ & $1.0795(0.5082-2.2928)$ & $15(46.87 \%)$ & $17(53.12 \%)$ & $1.572(0.7483-3.3024)$ \\
\hline
\end{tabular}

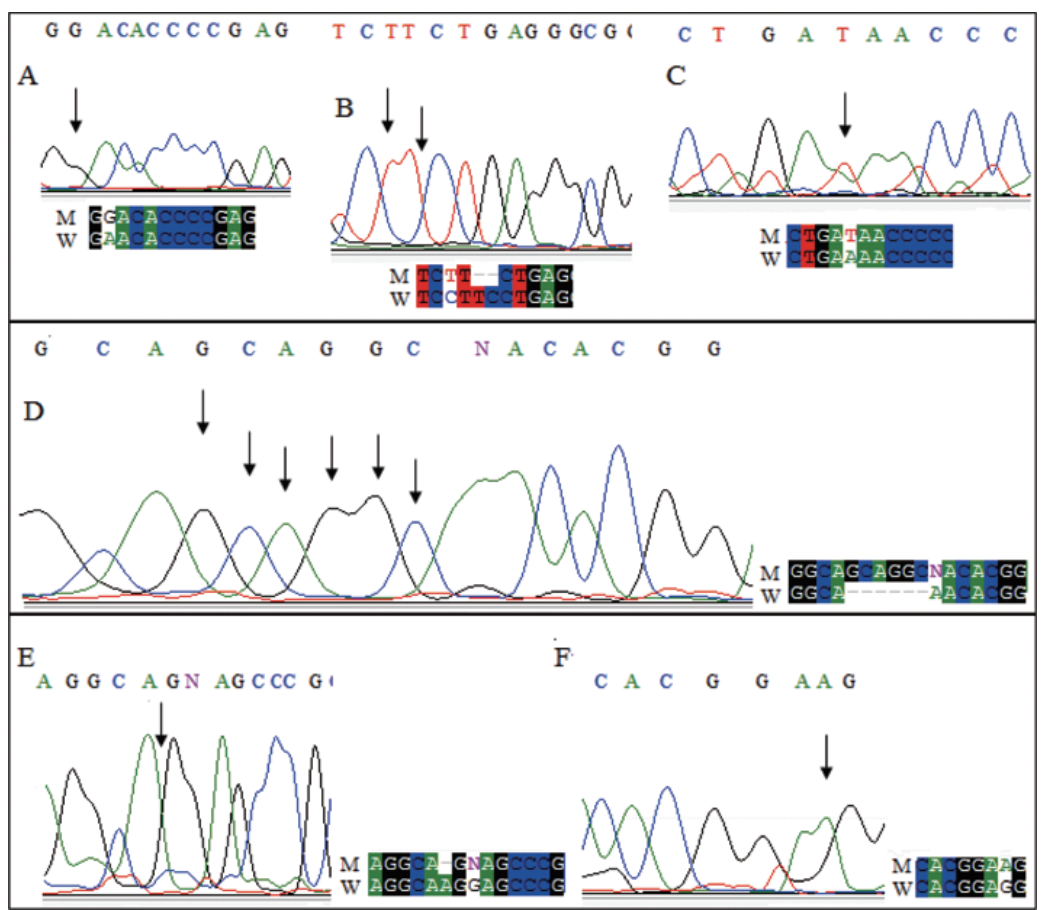

Fig. 1. Mutations observed in coding sequence of Gelsolin (study cohort\#1). A c.11A $>$ G, B c.985C $>\mathbf{T}$ and $\mathrm{C}$ c.1637A $>$ T: nonsynonymous missense mutations on exon 4, 11 and 15 respectively. D c.897_898insGCAGGC, B c.987_988del and E c.1436del: Frameshift mutations at exon 10, 11 and 14 respectively. F c.906G>A: Synonymous substitution at exon 10. Arrows show observed change, M is for mutated sequence while $\mathrm{W}$ is wild sequence. (Colours are visible in the online version of the article; http://dx.doi.org/10.3233/DMA-120952)

\subsection{Synonymous substitution}

Transition from $\mathrm{G}$ to A in exon 10, "906G $>$ A" resulted in synonymous substitution in 32 samples (Fig. 1F) as codon GAG changed to GAA and both encode for Glutamic acid.

When analyzed according to menopausal status, most common mutation in premenopausal women was frame shift mutation that was $906 \mathrm{G}>\mathrm{A}$ at exon 10 . Frame shift mutation 897_898__GCAGGC in at exon 10 was most observed among postmenopausal patients. This variation is also more frequent among patients in age group $<40$. While 987_988 C $>$ T, 987_988 $-/ \mathrm{TC}$ at exon 11 was wide spread among patients $>$ 40 years of age. Distribution of all these mutations according to age and menopausal status is summarized in Table 4.

\subsection{Expression of Gelsolin in human breast tissues}

This study further quantified the levels of Gelsolin transcript in breast tumor tissues (cohort\#2). Levels of Gelsolin transcripts were quantified in breast tumor tissues and were normalized by GAPDH. Gelsolin level in breast cancer tissues was lower compared with normal tissues and the difference was statistically significant $(p=0.03)$ (Fig. 2A).

When Gelsolin transcript level was observed in accordance to grades, a stepwise decrease in level of Gelsolin from grade 1 to grade 3 tumors was noted. How- 


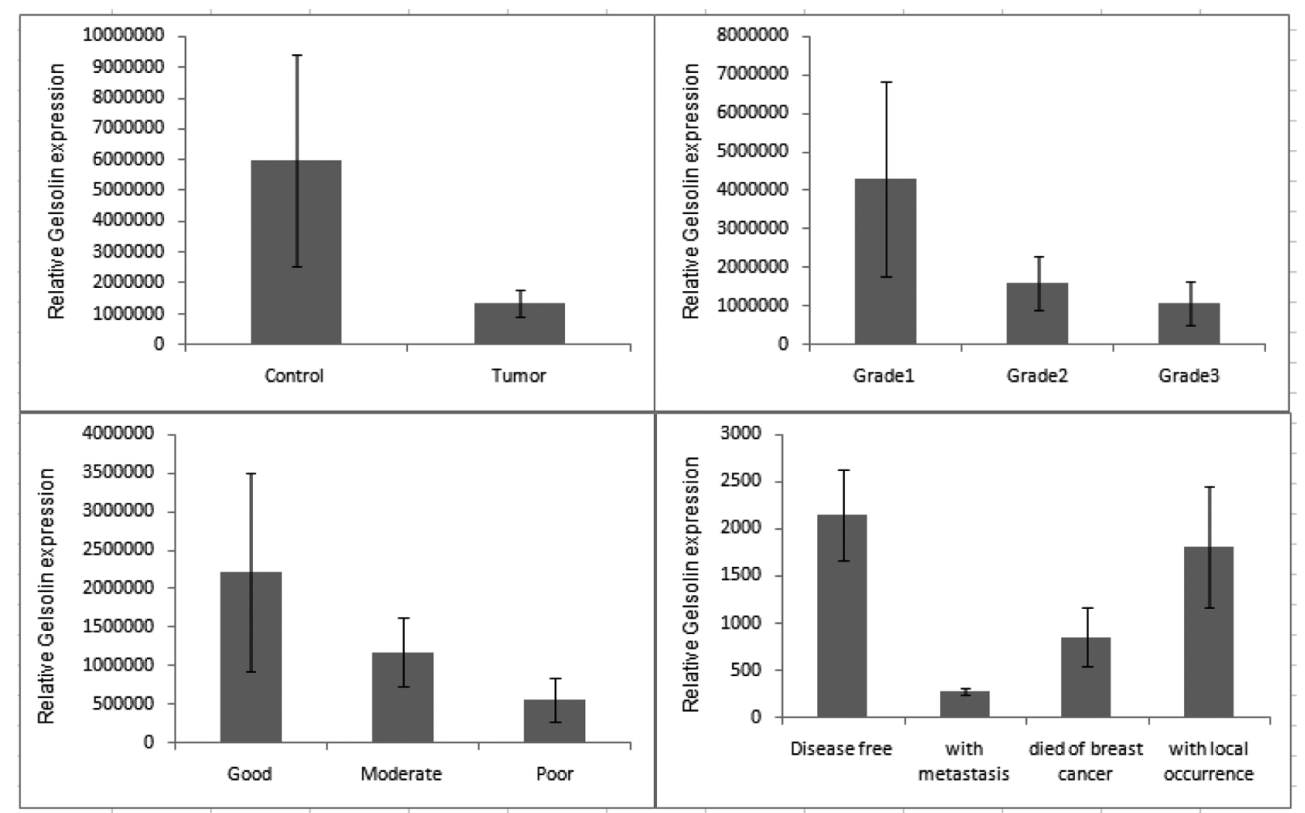

Fig. 2. Quantitative analysis of Gelsolin transcript levels in the study cohort\#2 in control and tumor tissues $(p=0.03)(\mathrm{A})$, Relative expression of Gelsolin in breast cancer tissues in connection with grades (B), predicted prognosis was based on the NPI value of each patient and that good, moderate and poor prognosis had NPI value either $<3.4,3.4-5.4$ or $>5.4$. (C). Patients who develop metastasis $(p=0.002)$ and who died of breast cancer $(p=0.03)$ had significantly low level of Gelsolin than those who were disease free at final clinical outcome (D).

ever, the difference observed was not significant $(p=$ 0.31 and $p=0.21$, grade 1 vs. grade 2 and grade 1 vs. grade 3 respectively) (Fig. 2B). Nottingham prognostic index (NPI) was calculated to determine prognosis following surgery for breast cancer. Patients were divided in to three groups, good, moderate and poor prognosis based on the NPI value $<3.4,3.4-5.4$ or $>5.4$. Its value is calculated using three pathological criteria that are size of the lesion, number of involved lymph nodes and grade of the tumor. Although there is a gradual decrease in Gelsolin transcript level in tumors with NPI value $<3.4$ (good prognosis) to $>5.4$ (poor prognosis) but this difference is not statistically significant $(p=$ 0.43 and $p=0.26$, good vs moderate and good vs poor prognosis respectively) (Fig. 2C).

Based on the clinical outcome at the final follow up, patients were divided into following categories; those who remained disease free, with metastatic diseases, with local recurrence, and those who died of breast cancer (patients died of causes other than breast cancer were excluded from the current analysis). As can be seen from Fig. 2D, patients who remained disease free has the highest levels of Gelsolin amongst all the patients. It is interesting to note that patients who developed metastasis and who died of breast cancer exhibited significantly lower levels compared with those who remained disease free $(p=0.002$ and $p=0.03$, respectively).

\section{Discussion}

Multistage model of carcinogenesis proposes the growth of consecutive genetic abnormalities in oncogenes and tumor suppressor genes during tumor progression [45]. One of the most fundamental characteristics of malignant and transformed cells is the aberrant organization of the cytoskeleton [10].

Gelsolin, one of the major actin-binding proteins, is widely expressed by normal cells [38] and may be down-regulated with transformation of multiple cell types, including breast epithelium [31,40]. It has therefore been considered a candidate tumor suppressor gene $[6,34,47]$. Although gelsolin-null mice survive, they have multiple defects in cell morphology and motility [61].

Purpose of this study was to screen Gelsolin for germ line mutations in sporadic breast cancer cases and to verify the expressional profile of Gelsolin in breast cancer patients, of Pakistani population and to compare it with the clinical data. Different risk factors were also analyzed in association with breast cancer in patients but no role of any of these factors was observed in 
studied population which is in accordance with other studies [54].

Gelsolin consists of six domains S1-S6 [6,28,33,41]. Different types of mutations were observed in these domains in this study at germline level. Missense mutation observed at exon 4 resulted in change in amino acid Glutamine to Glycine at position 4. When analyzed by Alamut biosoftware version 2.0, this change was found to be present in highly conserved nucleotide (score: 0.99 [0-1]) and in moderately conserved amino acid (considering 15 species). This change was tolerated as was analyzed by SIFT (score was 0.23). Same is the case with substitution $\mathrm{A}>\mathrm{T}$ at exon 15 which was observed in S5 domain, C-terminal of gelsolin. Mutation in this domain can impair nucleation of actin filaments [10]. Its SIFT score is 0.07 and this variation in Gelsolin is also tolerated. Missense mutation resulted from substitution at exon 11 that is $\mathrm{C}>\mathrm{T}$ changes amino acid Leucine in to phenylalanine in putative type $2, \mathrm{Ca}^{+2}$ binding site in $\mathrm{S} 2$ domain. Changes in $\mathrm{Ca}^{+2}$ binding site might hinder $\mathrm{Ca}^{+2}$ binding thus, Gelsolin functions [41]. This change is deleterious according to SIFT score (0.02). SIFT score less than 0.05 is considered deleterious [49].

It was observed that two additional amino acids, Alanine and Glycine were added at exon 10 in S3 domain of Gelsolin, in consequence of insertion of 6 base pairs. This S3 domain of Gelsolin is important in severing of actin filaments and is functionally relevant for regulation of Gelsolin activities [10,56]. Two deletion mutations that were observed at exon 11 and exon 14 interrupt reading frame prematurely. In exon 11 deletion of two nucleotides i.e. c.987_988del, replaced codon Pro330 by a STOP codon in ion binding site which lies in S3 domain and is important in binding of $\mathrm{Ca}^{+2}$ and polyphosphoinositide [10]. Mutation in this site could impair Gelsolin functions. Deletion at exon 14 , c.1436del creates a frame shift starting at codon Lys479. Resultant new reading frame ends in a STOP codon, 6 positions downstream and mRNA produced might be targeted for nonsense mediated decay (NMD). This mutation is also important in context that it is in actin binding interface in S4 domain of Gelsolin [10, 41].

As all these mutations were observed in important domains of Gelsolin so they may be important in context of their consequence and could contribute to growth and behavioral defects. Data generated in this study shows that all mutations described may play a significant role in presenting Gelsolin as a potential risk factor for breast cancer.
Variations in Gelsolin expression may play an important role in the development of breast cancer and serve as a biomarker of prognostic diagnostic importance [45]. In this study expression of Gelsolin was observed in 60 tumor samples along with their controls by Q-PCR. Down regulation of Gelsolin was confirmed by quantitative PCR analysis. It was noted that Gelsolin transcript levels were significantly lower in tumor tissues compared to controls. There is consistent decrease in gelsolin mRNA levels associated with higher tumor grade or poor prognosis. However, these differences do not appear to be statistically significant. Small sample size might be the reason for non- significant results.

The most important observation here is the link between level of Gelsolin expression and the clinical outcome. A highly significant link was observed between low levels of expression and a poor clinical outcome and metastatic development and overall survival. It is perceived that role of Gelsolin as a tumor suppressor depends upon the type of cancer [25]. It might be the reason that no difference was observed in Gelsolin levels in local occurrence and in disease free individuals.

This data indicate that Gelsolin may act as a potential prognostic indicator and the molecule may act as a protective factor in patients with breast cancer. In many cancers, down regulation of Gelsolin has been identified as a factor mediating aberrant cytoskeletal organization. Reduced levels of Gelsolin were observed in bladder cancer [45], breast cancer [19], non-small cell lung cancer (NSCLC) [15], gastric cancer [29], osteosarcoma [55] and in ovarian cancer [3].

Present study shows that Gelsolin is of crucial importance and is inversely correlated with metastatic development of breast cancer. Mutations described here suggest that there is a possible contribution of these variants in genomic instability of Gelsolin which can lead towards metastatic potential of breast cancer.

Results from this work suggest that an association may exist between mutational spectrum of Gelsolin, its down regulation and breast cancer metastasis. Concluded from literature survey it might be the first study reporting germline mutations in Gelsolin in breast cancer patients. Further, this is a first report of Gelsolin screening in breast cancer patients from this particular study cohort.

\section{Acknowledgement}

This study was supported by Higher Education Commission of Pakistan (HEC). Authors would like to ac- 
knowledge patients and normal individual who contributed to this research work. We also acknowledge Nuclear medicine, Oncology and Radiotherapy Institute (NORI), Pakistan Institute of Medical Sciences (PIMS) Islamabad Pakistan for sample collection and Metastasis and Angiogenesis Research Group, Cardiff University School of Medicine Cardiff, UK, for experimental help.

\section{Conflict of interest}

Authors declare that they have no conflict of interest.

\section{References}

[1] A. D. Thor, S. M. Edgerton, S. Liu, D. H. Moore and D. J. Kwiatkowski, Gelsolin as a negative prognostic factor and effector of motility in erbB-2-positive epidermal growth factor receptor-positive breast cancers, Clin Cancer Res 7 (2001), 2415-24.

[2] A. J. Sanders, C. Parr, M. D. Mason and W. G. Jiang, Suppression of hepatocyte growth factor activator inhibitor-1 leads to a more aggressive phenotype of prostate cancer cells in vitro, Int J Mol Med 20 (2007), 613-19.

[3] A. Noske, C. Denkert, H. Schober, C. Sers, B. Zhumabayeva, W. Weichert, M. Dietel and K. Wiechen, Loss of Gelsolin expression in human ovarian carcinomas, Eur J Cancer 41 (2005), 461-9.

[4] A.V. Abbeele, V. D. Corte, K. Van Impe, E. Bruyneel, C. Boucherie, M. Bracke, J. Vandekerckhove and J. Gettemans, Downregulation of gelsolin family proteins counteracts cancer cell invasion in vitro, Cancer Letters 255 (2007), 57-70.

[5] C. C. Thompson, F. J. Ashcroft, S. Patel, G. Saraga, D. Vimalachandran, W. Prime, F. Campbell, A. Dodson, R. E. Jenkins, N. R. Lemoine, T. Crnogorac-Jurcevic, H. L. Yin and E. Costello, Pancreatic cancer cells over express gelsolin family capping proteins which contribute to their cell motility, Gut 56 (2007), 95-106.

[6] C. Chaponnier and G. Gabbiani, Gelsolin modulation in epithelial and stromal cells of mammary carcinoma, Am. J Pathol 134 (1989), 597-603.

[7] C. Chaponnier, A. J. Paul and H. L. Yin, The Actin Filamentsevering Domain of Plasma Gelsolin, The Journal of Cell Biology 103 (1986), 1473-81.

[8] C. G. dos Remedios, D. Chhabra, M. Kekic, I. V. Dedova, M. Tsubakihara, D. A. Berry and N. J. Nosworthy, Actin binding proteins: Regulation of cytoskeletal microfilaments. Physiol 83 (2003), 433-73.

[9] D. J. Kwiatkowski, Functions of gelsolin: Motility, signaling, apoptosis, cancer. Curr Opin Cell Bio 11 (1999), 103-8.

[10] D. Yamazaki, S. Kurisu and T. Takenawa, Regulation of cancer cell motility through actin reorganization, Cancer Sci 96 (2005), 379-86.

[11] D. B. Shieh, I. W. Chen, T. Y. Wei, C. Y. Shao, H. J. Chang, C. H. Chung, T. Y. Wong and Y. T. Jin, Tissue expression of gelsolin in oral carcinogenesis progression and its clinicopathological implications, Oral Oncol 42 (2006), 599-606.
[12] E. Irobi, L. D. Burtnick, D. Urosev, K. Narayan and R. C. Robinson, From the first to the second domain of gelsolin: A common path on the surface of actin? FEBS Lett 552 (2003), 86-90.

[13] F. Yu, H. Sun, P. Janmey and H. Yin, Identification of a Polyphosphoinositide-binding sequence in an actin monomerbinding domain of gelsolin, Jour Biol Chem 267 (1992), 14616-21.

[14] H. Choe, L. D. Burtnick, M. Mejillano, H. L. Yin, R.C. Robinson and S. Choe, The calcium activation of gelsolin: Insights from the 3A structure of the G4-G6/actin complex, J Mol Biol 324 (2002), 691-702.

[15] H. Dosaka-Akita, F. Hommura, H. Fujita, I. Kinoshita, M. Nishi, T. Morikawa, H. Katoh, Y. Kawakami and N. Kuzumaki, Frequent loss of gelsolin expression in non-small cell lung cancers of heavy smokers, Cancer Res 58 (1998), 322-7.

[16] H. Fujita, F. Okada, J-I Hamada, M Hosokawa, T Moriuchi, R. C. Koya and N. Kuzumaki, Gelsolin functions as a metastasis suppressor in B16-BL6 mouse melanoma cells and requirement of the carboxyl-terminus for its effect, Int J Cancer $\mathbf{9 3}$ (2001), 773-780.

[17] H. Fujita, L. E. Laham, P. A. Janmey, D. J. Kwiatkowski, T. P. Stossel, Y. Banno, Y. Nozawa, L. Müllauer, A. Ishizaki and N. Kuzumaki, Functions of [His321] gelsolin isolated from a flat revertant of ras-transformed cells, Eur J Biochem 229 (1995), 615-20.

[18] H. K. Lee, D. Driscoll, H. Asch, B. Asch and P. J. Zhang, Down regulated gelsolin expression in hyperplastic and neoplastic lesions of the prostate, Prostate 40 (1999), 14-19.

[19] H. L. Asch, J. S. Winston, S. B. Edge, P. C. Stomper and B. B. Asch, Down-regulation of gelsolin expression in human breast ductal carcinoma in situ with and without invasion, Breast Cancer Res Treat 55 (1999), 179-88.

[20] H. L. Asch, K. Head, Y. Dong, F. Natoli, J. S. Winston, J. L. Connolly and B. B. Asch, Widespread loss of gelsolin in breast cancers of humans, mice, and rats, Cancer Res 56 (1996), 4841-45.

[21] H. Q. Sun, M. Yamamoto, M. Mejillano and H. L. Yin, Gelsolin, a multifunctional actin regulatory protein, $\mathrm{J}$ Biol Chem 274 (1999), 33179-82.

[22] H. Su, T. Wang, H. Dong and H. Ren, The Villin/Gelsolin/ Fragmin Superfamily proteins in plants, JIPB 49 (2007), 1183-1191.

[23] H. Tanaka, R. Shirkoohi, K. Nakagawa, H. Qiao, H. Fujita, F. Okada, J. I. Hamada, S. Kuzumaki, M. Takimoto and N. Kuzumaki, siRNA gelsolin knockdown induces epithelial - mesenchymal transition with a cadherin switch in human mammary epithelial cells, Int J Cancer 118 (2005), 1680-91.

[24] I. Mahjabeen, R. M. Baig, N. Masood, M. Sabir, F. A. Malik and M. A. Kayani, Sequence Variation of the OGG1 Gene in Head and Neck Cancer Patients in Pakistan, Asian Pacific $J$ Cancer Prev 12 (2011), 2359-63.

[25] J. Gettemans, A. V. Abbeele, A.De Ganck, K. Meerschaert, J. Vandekerckhobe and V. de Corte, Gelsolin and Tumor Metastasis: Friend or Foe? in: New development in metastasis suppressor research, New York, Nova Science Publishers, 2007, pp. 103-121.

[26] J. E. Cho, W. il Park, D. C. Kim, H. J. Kim, S. W. Kim, J. M. Kang and J. H. Cho, Down-regulation of gelsolin may play a role in the progression of inverted papilloma through an antiapoptotic mechanism, Am J Rhinol Allergy 26 (2012), 177-82.

[27] J. G. Kiselar, P. A. Janmey, S. C. Almo and M. R. Chance, 
Structural analysis of gelsolin using synchrotron protein foot printing, Mol Cell Proteomics 2 (2003), 1120-32.

[28] J. H. Hartwig and D. J. Kwiatkowski, Actin binding proteins, Curr Opin Cell Biol 3 (1991), 87-97.

[29] J. H. Kim, Y. K. Choi, H. J. Kwon, H. K. Yang, J. H. Choi and D. Y. Kim, Down regulation of gelsolin and retinoic acid receptor beta expression in gastric cancer tissues through histone deacetylase, J Gastroenterol Hepatol 19 (2004), 218-24.

[30] J. Rao, D. Seligson, H. Visapaa, S. Horvath, M. Eeva, K. Michel, A. Pantuck, A. Belldegrun and A. Palotie, Tissue microarray analysis of cytoskeletal actin-associated biomarkers gelsolin and E-cadherin in urothelial carcinoma, Cancer 95 (2002), 1247-57.

[31] J. S. Winston, H. L. Asch, P. J. Zhang, S. B. Edge, A. H. Hyland and B. B. Asch, Down-regulation of gelsolin correlates with the progression to breast cancer, Breast Cancer Res Treat $\mathbf{6 5}$ (2001), 11-2.

[32] J. S. Winston, H. L. Asch, P. J. Zhang, S. B. Edge, A. H. Hyland and B. B. Asch, Down-regulation of gelsolin correlates with the progression to breast cancer, Breast Cancer Res Treat 65 (2001), 11-2.

[33] J. Vandekerckhove, Actin binding proteins, Curr Opin Cell Biol 2 (1990), 41-50.

[34] J. Vanderkeckhove, G. Gauw, K. Vancompenolle, B. Honore and J. Celis, Comparative two-dimensional gel analysis and micro sequencing identifies gelsolin as one of the most prominent down-regulated markers of transformed human fibroblast and epithelial cells, J Cell Biol 111 (1990), 95-102.

[35] J. Yang, D. Tan, H. L. Asch, H. Swede, G. Bepler, J. Geradts and K. B. Moysich, Prognostic significance of gelsolin expression level and variability in non-small cell lung cancer, Lung Cancer 46 (2004), 29-42.

[36] J. Yang, N. Ramnath, K. B. Moysich, H. L. Asch, H. Swede, S. J. Alrawi, J. Huberman, J. Geradts, J. S. Brooks and D. Tan, Prognostic significance of MCM2, Ki-67 and gelsolin in non small cell lung cancer, BMC Cancer 6 (2006), 203-13.

[37] K. Haga, H. Fujita, M. Nomoto, A. Sazawa, K. Nakagawa, T. Harabayashi, N. Shinohara, M. Takimoto, K. Nonomura and N. Kuzumaki, Gelsolin gene silencing involving unusual hypersensitivities to dimethylsulfate and $\mathrm{KMnO} 4$ in vivo foot printing on its promoter region, Int J Cancer 111 (2004), 87380.

[38] K. Narayan, S. Chumnarnsilpa, H. Choe, E. Irobi, D. Urosev, U. Lindberg, C. E. Schutt, L. D. Burtnick and R. C. Robinson, Activation in isolation: exposure of the actin-binding site in the C-terminal half of gelsolin does not require actin, FEBS Lett 552 (2003), 82-85.

[39] K. Uchida, N. Masumori, A. Takahashi, N. Itoh, K. Kato, R. J. Matusik and T. Tsukamoto, Murine androgen-independent neuroendocrine carcinoma promotes metastasis of human prostate cancer cell line LNCaP, Prostate 66 (2006), 536-45.

[40] L. A. Harold, H. Karen, D. Yan, N. Farah, J. C. Winston, L. C. James and B. A. Bonnie, Widespread Loss of Gelsolin in Breast Cancers of Humans, Mice, and Rats, CANCER RES $\mathbf{5 6}$ (1996), 4841-45.

[41] L. D. Burtnick, E. K. Koepf, J. Grimes, E. Y. Jones, D. I. Stuart, P. J. McLaughlin and R. C. Robinson. The Crystal Structure of Plasma Gelsolin: Implications for Actin Severing, Capping, and Nucleation, Cell 90 (1997), 661-70.

[42] L. Mullauer, H. Fujita, A. Ishizaki and N. Kuzumaki, Tumorsuppressive function of mutated gelsolin in ras-transformed cells, Oncogene 8 (1993), 2531-6.

[43] L. Mullauer, H. Fujita, H. Suzuki, M. Katabami, Y. Hitomi, Y. Ogiso and N, Kuzumaki, Elevated gelsolin and $\alpha$-actin ex- pression in a flat revenant RI of Ha-ras oncogene-transformed NIH/3T3 cells, Biochem Biophys Res Commun 7 (1990), 85259.

[44] M. Tanaka, A. Sazawa, N. Shinohara, Y. Kobayashi, Y. Fujioka, T. Koyanagi and N. Kuzumaki, Gelsolin gene therapy by retrovirus producer cells for human bladder cancer in nude mice, Cancer Gene Ther 6 (1999), 482-7.

[45] M. Tanaka, L. Miillauer, Y. Ogiso, H. Fujita, S. Moriya, K. Furuuchi, T. Harabayashi, N. Shinohara, T. Koyanagi and N. Kuzumaki, Gelsolin: A Candidate for Suppressor of Human Bladder Cancer, Cancer Research 11 (1995), 3228-32.

[46] M. U. Rashid, A. Zaidi, D. Torres, F. Sultan, A. Benner, B. Naqvi, A. R. Shakoori, A. Seidel-Renkert, H. Farooq, S. Narod, A. Amin and U. Hamann, Prevalence of BRCA1 and BRCA2 mutations in Pakistani breast and ovarian cancer patients, Int J Cancer 119 (2006), 2832-39.

[47] N. Sagawa, H. Fujita, Y. Banno, Y. Nozawa, H. Katoh and N. Kuzumaki, Gelsolin suppresses tumorigenicity through inhibiting PKC activation in a human lung cancer cell line, PPC10, Brit Jour of Canc 88 (2003), 606-12.

[48] P. A. Janmey and T. P. Stossel, Modulation of gelsolin function by phosphatidylinositol 4, 5-bisphosphate, Nature (Lond) 325 (1987), 362-4.

[49] P. C. Ng and S. Henikoff, SIFT: predicting amino acid changes that affect protein function, Nucleic Acids Res 31 (2003), 3812-14.

[50] P. J. McLaughlin, J. T. Gooch, H. G. Mannherz and A. G. Weeds, Structure of gelsolin segment 1-actin complex and the mechanism of filament severing, Nature 364 (1993), 685-92.

[51] P. Silacci, L. Mazzolai, C. Gauci, N. Stergiopulos, H. L. Yin and D. Hayoz, Gelsolin super family proteins: Key regulators of cellular functions, Cell Mol Life Sci 61 (2004), 2614-23.

[52] R. M. Baig, I. Mahjabeen, M. Sabir, N. Masood, S. Hafeez, F. A. Malik and M. A. Kayani, Genetic Changes in PTEN Gene and their Association with Breast Cancer in Pakistan, Asian Pacific J Cancer Prev 12 (2011), 2365-70.

[53] R. M. Porter, T. C. Holme, E. L. Newman, D. Hopwood, J. M. Wilkinson and A. Cuschieri, Monoclonal antibodies to cytoskeletal proteins: An immunohistochemical investigation of human colon cancer, J Pathol 170 (1993), 435-40.

[54] S. A. Gangat, A. Rehman, M. A. Ahmed and I. A. Memon, Pattern of aetiological and predisposing factors regarding carcinoma breast, Pak J surg 23 (2007), 7-13.

[55] S. Jin, J. Shen, J. Peng, J. Wang, G. Huang and M. Li, Decreased expression of serum gelsolin in patients with osteosarcoma, Chinese Medical Journal 125 (2012), 262-69.

[56] S. Kothakota, T. Azuma, C. Reinhard, A. Klippel, J. Tang, K. Chu, T. J. McGarry, M. W. Kirschner, K. Koths, D. J. Kwiatkowski and L. T. Williams, Caspase-3-generated fragment of gelsolin: Effector of morphological change in apoptosis. Science 278 (1997), 294-8.

[57] S. Langbein, J. Lehmann, A. Harder, A. Steidler, M. S. Michel, P. Alken and J. K. Badawi. Protein profiling of bladder cancer using the 2D-PAGE and SELDI-TOF-MS technique, Technol Cancer Res Treat 5 (2006), 67-72.

[58] S. Moriya, K. Yanagihara, H. Fujita and N. Kuzumaki, Differential expression of HSP90, gelsolin and GST-Tr in human gastric carcinoma cell lines, Int J Oncol 5 (1994), 1347-51.

[59] S. Sohail and S. N. I. Alam, Breast cancer in Pakistan - awareness and early detection, J Coll Physicians Surg Pak 17 (2007), 711-2.

[60] D. Shieh, J. Godleski, J. E. Herndon, T. Azuma, H. Mercer, D. J. Sugarbaker and D. J. Kwiatkowski, Cell motility as a 
prognostic factor in Stage I nonsmall cell lung carcinoma: The role of gelsolin expression, Cancer 85 (1999), 47-57.

[61] W. Witke, A. H. Sharpe, J. H. Hartwig, T. Azuma, T. P. Stossel, D. J. Kwiatkowski, Hemostatic, inflammatory, and fibroblast responses are blunted in mice lacking gelsolin, Cell 81 (1995), $41-51$.
[62] Y. Banno, T. Nakashima, T. Kumada, K. Ebisawa, Y. Nonomura and Y. Nozawa, Effects of gelsolin on human platelet cytosolic phosphoinositide-phospholipase C. isozymes, J Biol Chem 267 (1992), 6488-94. 


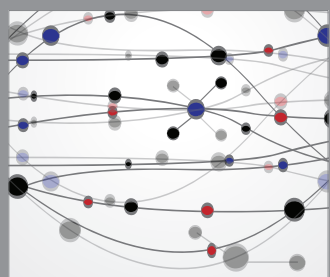

The Scientific World Journal
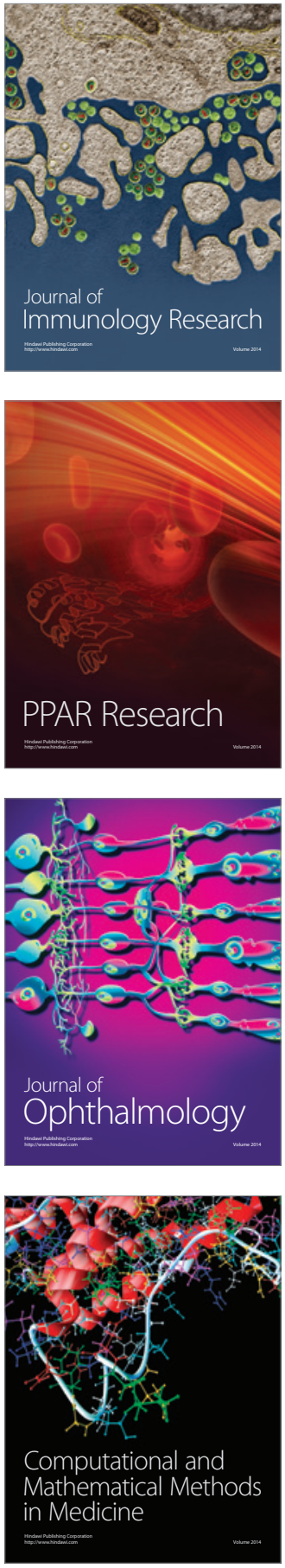

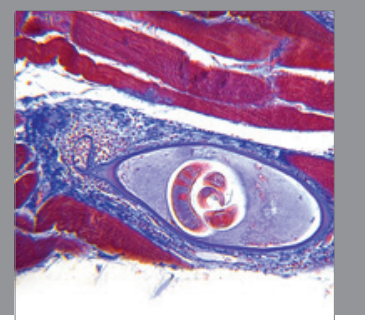

Gastroenterology

Research and Practice
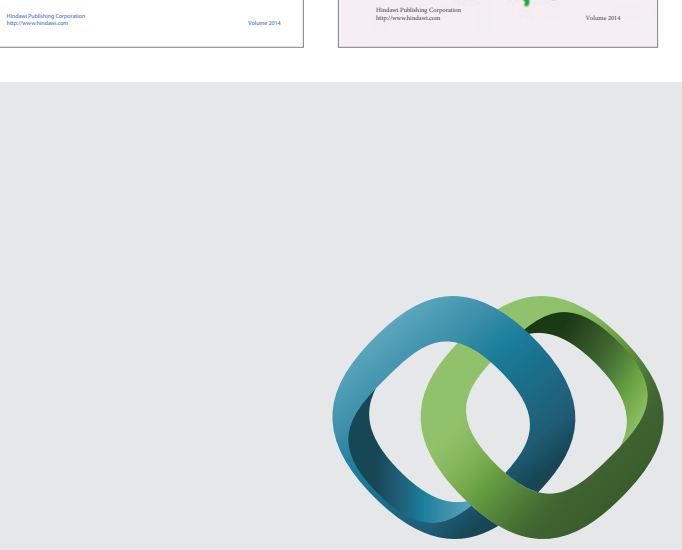

\section{Hindawi}

Submit your manuscripts at

http://www.hindawi.com
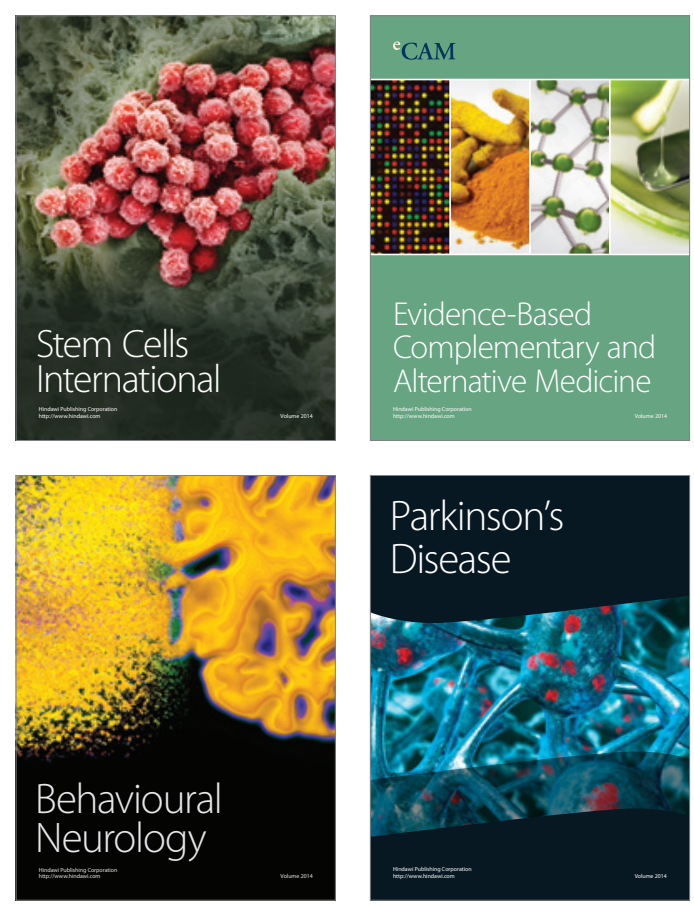

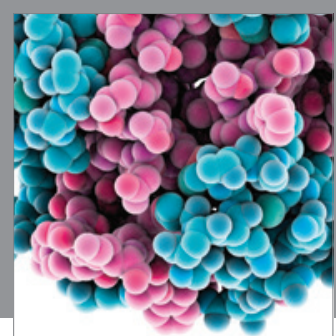

Journal of
Diabetes Research

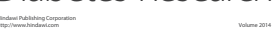

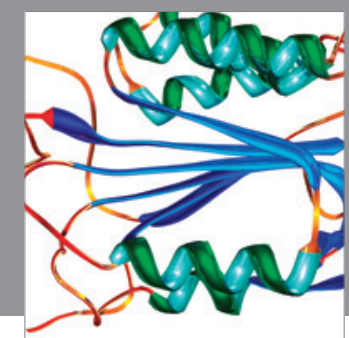

Disease Markers
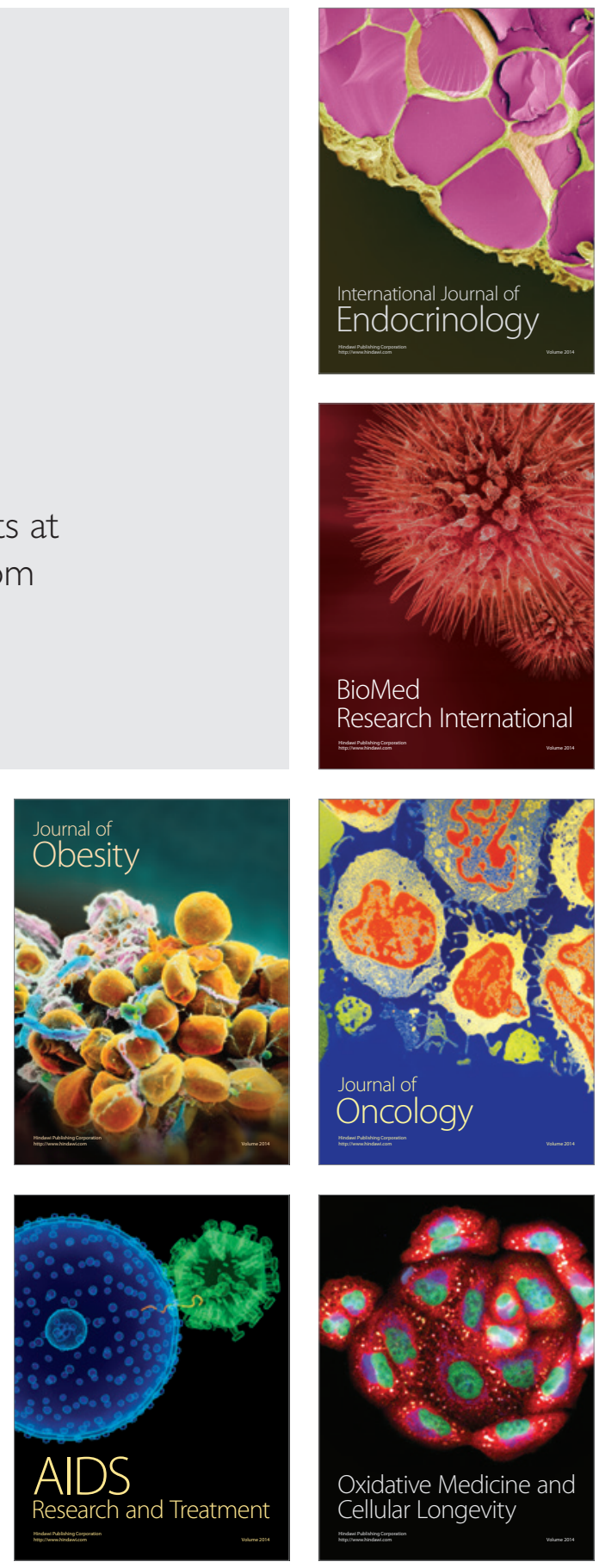